\title{
Altered Muscarinic and Nicotinic Receptor Densities in Cortical and Subcortical Brain Regions in Parkinson's Disease
}

\author{
K. W. Lange, F. R. Wells, *P. Jenner, and C. D. Marsden \\ Parkinson's Disease Society Brain Bank and University Department of Clinical Neurology, Institute of Neurology and The \\ National Hospital for Neurology and Neurosurgery; and *Parkinson's Disease Society Experimental Research Laboratories, \\ Pharmacology Group, Biomedical Sciences Division, King's College, London, England
}

\begin{abstract}
Muscarinic and nicotinic cholinergic receptors and choline acetyltransferase activity were studied in postmortem brain tissue from patients with histopathologically confirmed Parkinson's disease and matched control subjects. Using washed membrane homogenates from the frontal cortex, hippocampus, caudate nucleus, and putamen, saturation analysis of specific receptor binding was performed for the total number of muscarinic receptors with $\left[{ }^{3} \mathrm{H}\right]$ quinuclidinyl benzilate, for muscarinic $M_{1}$ receptors with $\left[{ }^{3} \mathrm{H}\right]$ pirenzepine, for muscarinic $\mathrm{M}_{2}$ receptors with $\left[{ }^{3} \mathrm{H}\right]-$ oxotremorine-M, and for nicotinic receptors with $(-)-\left[{ }^{3} \mathrm{H}\right]-$ nicotine. In comparison with control tissues, choline acetyltransferase activity was reduced in the frontal cortex and hippocampus and unchanged in the caudate nucleus and putamen of parkinsonian patients. In Parkinson's disease the maximal binding site density for $\left[{ }^{3} \mathrm{H}\right]$ quinuclidinyl benzilate was increased in the frontal cortex and unaltered in the hippocampus, caudate nucleus, and putamen. Specific $\left[{ }^{3} \mathrm{H}\right]$ pirenzepine binding was increased in the frontal cortex, unaltered in the hippocampus, and decreased in the caudate nucleus and putamen. In parkinsonian patients $B_{\max }$ values
\end{abstract}

for specific $\left[{ }^{3} \mathrm{H}\right]$ oxotremorine-M binding were reduced in the cortex and unchanged in the hippocampus and striatum compared with controls. Maximal $(-)-\left[{ }^{3} \mathrm{H}\right]$ nicotine binding was reduced in both the cortex and hippocampus and unaltered in both the caudate nucleus and putamen. Alterations of the equilibrium dissociation constant were not observed for any ligand in any of the brain areas examined. The present results suggest that both the innominatocortical and the septohippocampal cholinergic systems degenerate in Parkinson's disease. The reduction of cortical $\left[{ }^{3} \mathrm{H}\right]$ oxotremorine-M and (-)- $\left[{ }^{3} \mathrm{H}\right]$ nicotine binding is compatible with the concept that significant numbers of the binding sites labelled by these ligands are located on presynaptic cholinergic nerve terminals, whereas the increased $\left[{ }^{3} \mathrm{H}\right]-$ pirenzepine binding in the cortex may reflect postsynaptic denervation supersensitivity. Key Words: AcetylcholineCholine acetyltransferase-Muscarinic receptors-Nicotinic receptors-Parkinson's disease. Lange K. W. et al. Altered muscarinic and nicotinic receptor densities in cortical and subcortical brain regions in Parkinson's disease. $J$. Neurochem. 60, 197-203 (1993).
Present evidence suggests that a central cholinergic deficiency is the basis of some aspects of cognitive dysfunction (Bartus et al., 1982). In rats and nonhuman primates, a subcorticocortical cholinergic deficiency is associated with profound cognitive alterations (Ridley et al., 1985; Everitt et al., 1987). In Alzheimer's disease the cortical cholinergic deficiency, as measured by choline acetyltransferase (ChAT) activity, has been related to intellectual impairment (Perry et al., 1978). Dementia occurs in a significant number of patients with Parkinson's disease but without substantial pathological changes typi- cal of Alzheimer's disease (Candy et al., 1983; Perry et al., 1985). The innominatocortical and septohippocampal cholinergic systems appear to be damaged in Parkinson's disease, because severe neuronal loss occurs in the substantia innominata (Candy et al., 1983; Whitehouse et al., 1983) and ChAT activity is decreased in the neocortex and hippocampus (Ruberg et al., 1982; Dubois et al., 1983). The loss of cortical ChAT activity in parkinsonian subjects has been reported to correlate with the severity of dementia ( $\mathrm{Ru}$ berg et al., 1982; Perry et al., 1985).

The status of muscarinic and nicotinic cholinergic
Received October 15, 1991; revised manuscript received June 5, 1992; accepted June 17, 1992.

Address correspondence and reprint requests to Dr. K. W. Lange at his present address: Department of Clinical Neurochemistry, University of Würzburg, Füchsleinstrasse 15, 8700 Würzburg, F.R.G.
Abbreviations used: ChAT, choline acetyltransferase; QNB, quinuclidinyl benzilate. 
receptor subtypes in Parkinson's disease is less clear. Total muscarinic binding, identified by $\left[{ }^{3} \mathrm{H}\right]-$ quinuclidinyl benzilate $\left.\left({ }^{3} \mathrm{H}\right] \mathrm{QNB}\right)$, has been reported to be increased in the neocortex and unchanged in the striatum of patients with Parkinson's disease in comparison with control subjects (Reisine et al., 1977; Ruberg et al., 1982; Dubois et al., 1983). The increase of muscarinic receptor binding in the cortex may be due to a denervation-induced increase of postsynaptic muscarinic receptors (Dubois et al., 1983). Selective muscarinic ligands might be used to differentiate between receptor subtypes located at pre- and postsynaptic sites. The muscarinic antagonist pirenzepine binds preferentially to $M_{1}$ muscarinic receptors, which are thought to be located postsynaptically, rather than to $M_{2}$ receptors, whereas QNB binds with the same affinity to both receptor subtypes (Hammer et al., 1980; Watson et al., 1983). Muscarinic receptors of the $M_{2}$ subtype can be selectively labelled by $\left[{ }^{3} \mathrm{H}\right]$ oxotremorine-M (Bevan, 1984; Spencer et al., 1986). In addition, little attention has been paid to changes in nicotinic cholinergic receptors. $\left[{ }^{3} \mathrm{H}\right]-$ Nicotine has been described as a ligand for the characterization of nicotinic binding sites in the rat brain (Romano and Goldstein, 1980), and (-)-[ $\left[{ }^{3} \mathrm{H}\right]$ nicotine has been shown to be highly specific for nicotinic receptors in the human brain (Shimohama et al., 1985).

To further elucidate the alterations of cholinergic systems in Parkinson's disease and their relation to dementia, we have examined ChAT activity as an index of cholinergic innervation and receptor binding of $\left[{ }^{3} \mathrm{H}\right] \mathrm{QNB},\left[{ }^{3} \mathrm{H}\right]$ pirenzepine, $\left[{ }^{3} \mathrm{H}\right]$ oxotremorine-M, and $(-)-\left[{ }^{3} \mathrm{H}\right]$ nicotine in cortical and subcortical brain regions of demented and nondemented patients with Parkinson's disease.

\section{MATERIALS AND METHODS}

\section{Materials}

l-Quinuclidinyl [ phenyl-4- $\left.{ }^{3} \mathrm{H}\right]$ benzilate $\left(\left[{ }^{3} \mathrm{H}\right] \mathrm{QNB}\right.$; specific activity, $39 \mathrm{Ci} / \mathrm{mmol})$ and $(-)-\left[N-\right.$ methyl $\left.{ }^{3} \mathrm{H}\right]$ nicotine (specific activity, $63.5 \mathrm{Ci} / \mathrm{mmol}$ ) were purchased from Amersham International (Amersham, Buckinghamshire, U.K.). [N-methyl $\left.{ }^{3} \mathrm{H}\right] \mathrm{Pirenzepine}$ (specific activity, $70.1 \mathrm{Ci} /$ $\mathrm{mmol}$ ), $\left[\right.$ methyl $\left.{ }^{3} \mathrm{H}\right]$ oxotremorine-M acetate (specific activity, $84.9 \mathrm{Ci} / \mathrm{mmol}$ ), and $\left[{ }^{14} \mathrm{C}\right]$ acetyl-CoA (specific activity, $53 \mathrm{mCi} / \mathrm{mmol}$ ) were from New England Nuclear (DuPont, Stevenage, Hertfordshire, U.K.). The protein assay was obtained from Bio-Rad Laboratories (Hemel Hempstead, Hertfordshire, U.K.). Atropine sulfate and polyethylenimine were purchased from Sigma (Poole, Dorset, U.K.). The liquid scintillation cocktail (Scintillator 299 TM) was from Packard (Pangbourne, Berkshire, U.K.). All other reagents were of analytical grade and were obtained commercially.

\section{Brain tissue}

Tissue samples from the frontal cortex (Brodmann area 9), hippocampus, caudate nucleus, and putamen were obtained from 10 patients who died with the clinical diagnosis of idiopathic Parkinson's disease and from 10 age-matched control subjects with no evidence of neurological or psychiatric diseases (for patient details, see Table 1). Five parkinsonian patients had shown profound progressive disturbances in memory and cognitive impairment and had been clinically demented according to DSM IIl criteria (American Psychiatric Association, 1980). The parkinsonian patients had all received levodopa therapy up to the time of death and had not received anticholinergic medication. Parkinson's disease was confirmed neuropathologically by the presence of neuronal loss and Lewy bodies in the substantia nigra. The patients did not show neocortical neurofibrillary tangles or abundant neuritic plaques. Control subjects had not received any drugs known to affect the CNS. Pathological examination of the control brains revealed no abnormalities; in particular, there was no cell loss in the substantia nigra, and Lewy bodies were absent. According to the clinical notes, the subjects examined in this study had not been smokers for the last 2 years before their deaths. There was no difference between the Parkinson's disease and control groups with regard to the time from death to body refrigeration, the time from death to brain removal, or the time of storage of the frozen brain samples before neurochemical analysis.

At autopsy the brains were removed and divided midsagitally. One half brain was immediately frozen at $-20^{\circ} \mathrm{C}$ and transported on Cardice to the Brain Bank, where the tissue was frozen at $-70^{\circ} \mathrm{C}$ until dissection for neurochemical analyses took place. The other half brain was placed in $10 \%$ formol saline and was examined neuropathologically. Tissue samples were frozen for up to 2.5 years before biochemical analysis. Immediately before dissection for ChAT activity determination and receptor binding assays, frozen brain tissue was gradually raised in temperature to $-12^{\circ} \mathrm{C}$. The brainstem was then cut off between the upper margin of the pons and the lower border of the inferior colliculus to form a hindbrain block. A midbrain block was formed by cutting vertically from the posterior margin of the optic chiasm to the lower border of the corpus callosum. From this point, the brain was cut along the curved lower border of the corpus callosum to terminate at the superior margin of the superior colliculus. This block was removed by cutting in the sagittal plane along the lateral margins of the cerebral peduncle and tectum. The hemisphere was then sectioned coronally into 10 slices at $\sim 1.2-\mathrm{cm}$ intervals from the frontal lobe tips to the level of the splenium of the corpus callosum. Nuclear areas in the midbrain and coronal hemisphere sections were outlined by their anatomical colour/density features in contrast to adjacent structures identified by reference to standard manuals of neuroanatomy. Cerebral cortical areas were located according to Brodmann's scheme of localization. The brain tissue was removed in small fragments or narrow strips and stored in labelled tubes at $-70^{\circ} \mathrm{C}$ until biochemical analysis.

\section{Biochemical analysis}

Using washed membrane homogenates from the frontal cortex (Brodmann area 9), hippocampus, caudate nucleus, and putamen, saturation analysis of specific receptor binding was performed for the total number of muscarinic receptors with $\left[{ }^{3} \mathrm{H}\right] \mathrm{QNB}$ as ligand, for muscarinic $\mathrm{M}_{1}$ receptors with $\left[{ }^{3} \mathrm{H}\right]$ pirenzepine, for muscarinic $\mathrm{M}_{2}$ receptors with $\left[{ }^{3} \mathrm{H}\right]$ oxotremorine-M, and for nicotinic receptors with (-)$\left[{ }^{3} \mathrm{H}\right]$ nicotine. The maximal receptor number $\left(B_{\max }\right)$ and the equilibrium dissociation constant $\left(K_{\mathrm{D}}\right)$ were determined by assaying the binding of the tritiated ligands at different con- 
TABLE 1. Patient characteristics and details of postmortem procedures

\begin{tabular}{|c|c|c|c|}
\hline & \multirow[b]{2}{*}{ Control subjects } & \multicolumn{2}{|c|}{ Parkinson's disease } \\
\hline & & Without dementia & With dementia \\
\hline Age (years) & $73.1 \pm 5.5$ & $69.2 \pm 3.3$ & $78.2 \pm 2.6$ \\
\hline Female & 4 & 2 & $\frac{1}{3}$ \\
\hline Male & 6 & 3 & 2 \\
\hline Age at onset of Parkinson's disease (years) & - & $56.2 \pm 3.4$ & $63.6 \pm 1.8$ \\
\hline \multicolumn{4}{|l|}{ Duration of Parkinson's } \\
\hline disease (years) & - & $13.0 \pm 4.1$ & $14.6 \pm 2.9$ \\
\hline L-DOPA dosage at time of death (mg/day) & - & $303 \pm 88$ & $525 \pm 77$ \\
\hline Cell loss and presence of Lewy bodies in midbrain & No & Yes & Yes \\
\hline Caudate dopamine concentration (ng/g) & $2,836 \pm 396$ & $324 \pm 133^{a}$ & $297 \pm 152^{a}$ \\
\hline \multicolumn{4}{|l|}{ Time between death and } \\
\hline body refrigeration $(\mathrm{h})$ & $2.1 \pm 0.4$ & $2.8 \pm 0.2$ & $2.7 \pm 0.7$ \\
\hline Time between death and autopsy (h) & $19.6 \pm 2.4$ & $18.3 \pm 4.1$ & $17.9 \pm 4.0$ \\
\hline
\end{tabular}

Data are mean \pm SEM values. Caudate dopamine levels were measured by a standard HPLC with electrochemical detection technique (Weller et al., 1987). L-DOPA, L-3,4-dihydroxyphenylalanine.

${ }^{a} p<0.05$ compared with control values by Student's $t$ test.

centrations of $\left[{ }^{3} \mathrm{H}\right] \mathrm{QNB}$ (range, $10-300 \mathrm{pM}$ ), $\left[{ }^{3} \mathrm{H}\right]-$ pirenzepine $(0.5-64 \mathrm{n} M),\left[{ }^{3} \mathrm{H}\right]$ oxotremorine-M $(0.25-32$ $\mathrm{n} M)$, and $(-)-\left[{ }^{3} \mathrm{H}\right]$ nicotine $(0.5-64 \mathrm{n} M)$. Binding data were expressed as femtomoles of tritiated ligand specifically bound per milligram of protein.

For $\left[{ }^{3} \mathrm{H}\right] \mathrm{QNB}$ binding, tissue homogenates of each brain region examined were initially prepared in ice-cold $0.05 M$ sodium/potassium phosphate buffer $(\mathrm{pH} 7.4)$ by hand over a 30 -s period using 3 complete strokes of a Teflon-glass homogenizer. The homogenates were centrifuged $(48,000 \mathrm{~g}$ for $10 \mathrm{~min}$ at $4^{\circ} \mathrm{C}$ ). The resulting pellet was homogenized using a 10-s burst with a Polytron homogenizer (setting of 7; Kinematica, Luzern, Switzerland) at $4^{\circ} \mathrm{C}$ and then washed twice in fresh buffer and recentrifuged as above. The homogenate was finally resuspended in the sodium/potassium phosphate buffer. $\left[{ }^{3} \mathrm{H}\right] \mathrm{QNB}$ binding was carried out on tissue corresponding to $15-50 \mu \mathrm{g}$ of protein in a total volume of $7.0 \mathrm{ml}$, at $37^{\circ} \mathrm{C}$ for $60 \mathrm{~min}$. Nonspecific binding was determined by carrying out incubations in the presence of unlabelled atropine $(1 \mu M)$. After incubation for $60 \mathrm{~min}$, the reaction was stopped by addition of ice-cold assay buffer and rapid filtration under reduced pressure through glass fiber filters (Whatman $\mathrm{GF} / \mathrm{C}$ ), presoaked in assay buffer, with a Brandel cell harvester (Semat, St. Albans, Hertfordshire, U.K.). The filters were rinsed with three 5 -ml aliquots of buffer and dried for $\sim 12 \mathrm{~h}$. They were then placed into scintillation vials, and $5 \mathrm{ml}$ of scintillation fluid was added to extract tissue-bound radioactivity for $\sim 12 \mathrm{~h}$ at ambient temperature. Samples were cooled for $2-3 \mathrm{~h}$ before quantification by liquid scintillation spectrophotometry (model Tri-Carb 460C; Packard) at a counting efficiency of $45 \%$.

For $\left[{ }^{3} \mathrm{H}\right]$ pirenzepine binding, brain tissue homogenates were prepared as described for $\left[{ }^{3} \mathrm{H}\right] \mathrm{QNB}$ binding. The specific binding of $\left[{ }^{3} \mathrm{H}\right]$ pirenzepine was measured in parallel assays, which were conducted in the designated assay buffer as described above in a total volume of $0.1 \mathrm{ml}$, at $37^{\circ} \mathrm{C}$ for $60 \mathrm{~min}$, again using $1 \mu M$ atropine to define nonspecific binding. It was necessary to presoak $\mathrm{GF} / \mathrm{C}$ filters in aqueous polyethylenimine $(0.1 \%)$ for $30 \mathrm{~min}$ to reduce filter binding of the polar $\left[{ }^{3} \mathrm{H}\right]$ pirenzepine (Watson et al., 1983).

For $\left[{ }^{3} \mathrm{H}\right]$ oxotremorine-M and $(-)-\left[{ }^{3} \mathrm{H}\right]$ nicotine binding, brain tissue was suspended and homogenized in an ice-cold buffer (pH 7.4) containing $118 \mathrm{mM} \mathrm{NaCl}, 4.8 \mathrm{mM} \mathrm{KCl}, 2.5$ $\mathrm{m} M \mathrm{CaCl}_{2}, 1.2 \mathrm{mM} \mathrm{MgCl}_{2}$, and $20 \mathrm{~m} M$ HEPES. The homogenates were washed twice by centrifugation at $48,000 \mathrm{~g}$ for $10 \mathrm{~min}$ with intermediate homogenization with a Polytron (setting of $7,10 \mathrm{~s}, 4^{\circ} \mathrm{C}$ ) in fresh buffer.

For $\left[{ }^{3} \mathrm{H}\right]$ oxotremorine-M and $(-)-\left[{ }^{3} \mathrm{H}\right]$ nicotine binding, polypropylene tubes containing the ligand and tissue membranes (240-360 $\mu \mathrm{g}$ of protein) to a final volume of $250 \mu \mathrm{l}$ were incubated at $25^{\circ} \mathrm{C}$ for $10 \mathrm{~min}$. Nonspecific binding was defined as binding in the presence of $1 \mu M$ atropine or $10 \mu M(-)$-nicotine, respectively. The binding assay was terminated by addition of $4 \mathrm{ml}$ of ice-cold wash buffer (composition identical with that of incubation buffer, except that the HEPES concentration was reduced to $5 \mathrm{~m} M$ ) and then filtration under reduced pressure through Whatman GF/C glass fiber filters, previously soaked in a $0.1 \%$ solution of polyethylenimine. The filters were subsequently washed twice with $4 \mathrm{ml}$ of wash buffer.

All binding assays were carried out in triplicate, the values of which did not vary by $>8 \%$. Homogenates were added promptly to begin binding assays immediately after they were prepared. Total binding was limited to ensure that there would be no significant depletion of free ligand during the binding assay and that specific binding was always $>80 \%$ of total binding. All measurements of cholinergic binding sites and ChAT activity were made blind with respect to diagnosis.

Aliquots for the determination of the activity of ChAT (acetyl-CoA:choline $O$-acetyltransferase; EC 2.3.1.6) were removed from the tissue homogenates of each brain area examined. ChAT activity was determined by a radioenzymatic method measuring the formation of $\left[{ }^{14} \mathrm{C}\right]-$ acetylcholine from $\left[{ }^{14} \mathrm{C}\right]$ acetyl-CoA and choline (Fonnum, 1975). Tissue samples were homogenized in $10 \mathrm{~m} M$ EDTA ( $\mathrm{pH} 7.4)$. ChAT activity was expressed in nanomoles of acetylcholine formed per hour per milligram of protein.

The protein concentration was measured with the BioRad protein assay (Bradford, 1976) in aliquots of the membrane suspensions used in the receptor binding assays.

\section{Data analysis}

The $B_{\max }$ and the $K_{\mathrm{D}}$ were determined by Eadie-Hofstee analysis. Results are expressed as mean \pm SEM values. Demented and nondemented parkinsonian patients were com. 

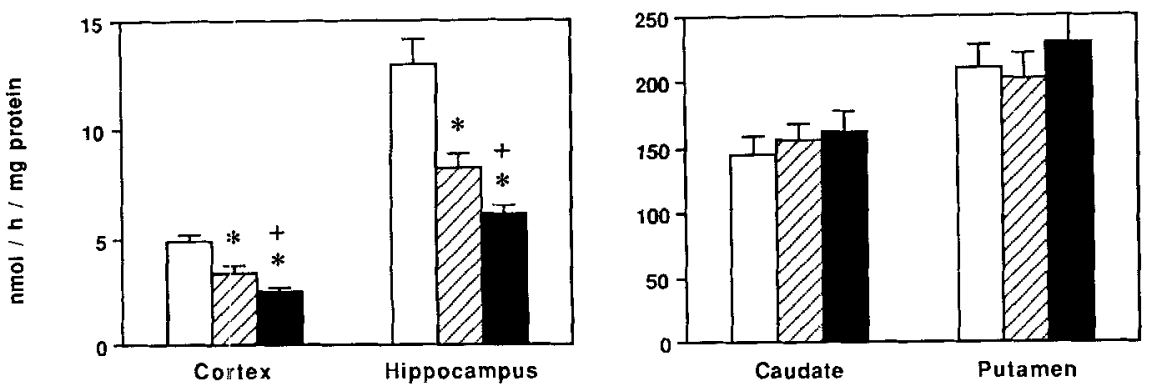

FIG. 1. ChAT activity, measured by the formation of $\left[{ }^{14} \mathrm{C}\right]$ acetylcholine from $\left[{ }^{14} \mathrm{C}\right]$ acetyl-CoA and choline, in different brain areas from 10 control subjects $(\square)$ and five nondemented (R) and five demented ( $\square$ ) patients with Parkinson's disease. Data are mean \pm SEM (bars) values. " $p<0.05$ compared with control values, ${ }^{+} p<0.05$ compared with nondemented patients with Parkinson's disease by Wilcoxon's rank-sum test. pared with control subjects by the nonparametric Wilcoxon's rank-sum test (Wilcoxon, 1945).

\section{RESULTS}

\section{ChAT activity}

ChAT activity was reduced in both frontal cortex and hippocampus of demented and nondemented patients with Parkinson's disease compared with control tissues (Fig. 1). In demented parkinsonian patients ChAT activity in the cortex and hippocampus was decreased to a greater extent than in nondemented patients. ChAT activity was unchanged in the caudate nucleus and putamen of parkinsonian subjects compared with controls.

\section{Muscarinic receptor binding}

In demented and nondemented parkinsonian subjects, the $B_{\max }$ for the total number of muscarinic receptors as measured by specific binding of $\left[{ }^{3} \mathrm{H}\right] \mathrm{QNB}$ was increased in the frontal cortex and unaltered in the hippocampus, caudate nucleus, and putamen (Fig. 2). Specific binding of $\left[{ }^{3} \mathrm{H}\right]$ pirenzepine was increased in the frontal cortex, unaltered in the hippocampus, and decreased in the caudate nucleus and putamen (Fig. 2). In Parkinson's disease $B_{\max }$ values for specific $\left[{ }^{3} \mathrm{H}\right]$ oxotremorine- $\mathrm{M}$ binding were reduced in the cortex and unchanged in the hippocampus and striatum compared with controls (Fig. 2). The $K_{\mathrm{D}}$ values for $\left[{ }^{3} \mathrm{H}\right] \mathrm{QNB},\left[{ }^{3} \mathrm{H}\right]$ pirenzepine, and $\left[{ }^{3} \mathrm{H}\right]-$ oxotremorine:-M did not differ between the groups of patients and control subjects in the brain areas examined.

\section{Nicotinic receptor binding}

Compared with the control group, the density of nicotinic receptors as identified by specific $(-)-\left[{ }^{3} \mathrm{H}\right]-$ nicotine binding was reduced in both the frontal cortex and hippocampus and unchanged in the caudate nucleus and putamen (Fig. 3). Alterations of $K_{\mathrm{D}}$ values for $(-)-\left[{ }^{3} \mathrm{H}\right]$ nicotine binding were not seen.

\section{DISCUSSION}

\section{ChAT activity}

The reduction of ChAT activity in the neocortex and hippocampus was more pronounced in demented than in nondemented parkinsonian subjects. This confirms the findings of previous reports $(\mathrm{Ru}-$ berg et al., 1982; Dubois et al., 1983; Smith et al., 1988). It has been shown that the decrease in cortical ChAT activity is correlated with the cell loss in the nucleus basalis of Meynert in patients with Parkin-
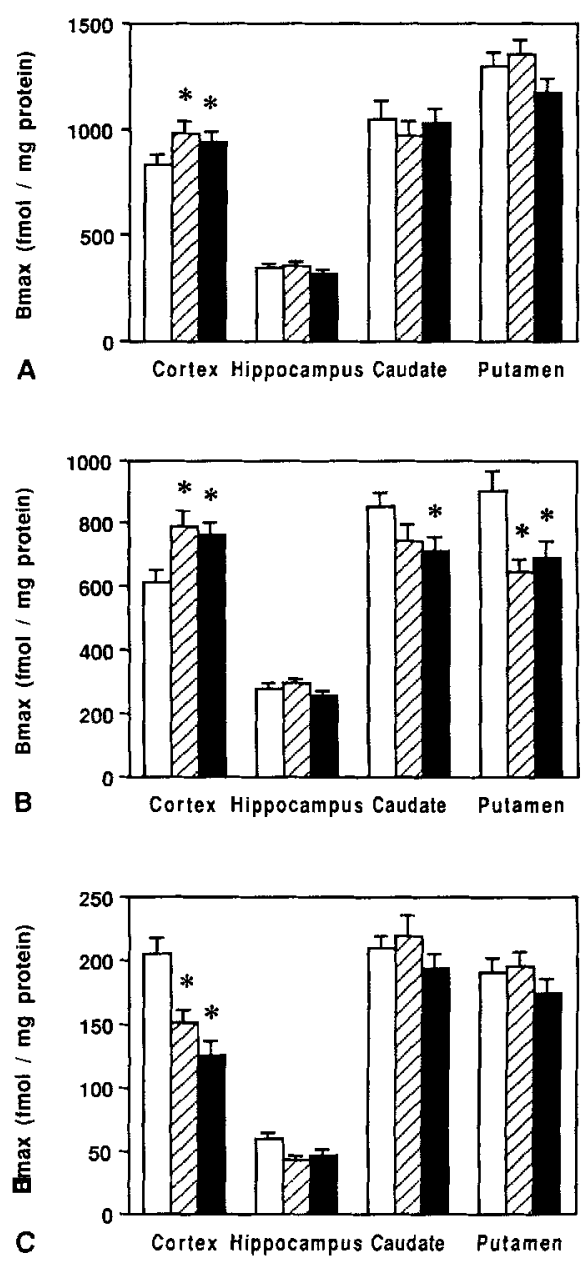

FIG. 2. Specific binding of $(A)\left[{ }^{3} H\right] O N B,(B)\left[{ }^{3} H\right] p i r e n z e p i n e$, and (C) $\left[^{3} \mathrm{H}\right]$ oxotremorine-M to muscarinic sites in different brain areas from 10 control subjects $(\square)$ and five nondemented (ए: demented $(\square)$ patients with Parkinson's disease. Saturation analyses were performed in tissue homogenates incubated with $10-$ $300 \mathrm{pM}\left[{ }^{3} \mathrm{H}\right] \mathrm{QNB}, 0.5-64 \mathrm{nM}\left[{ }^{3} \mathrm{H}\right]$ pirenzepine, and 0.25-32 $\mathrm{nM}$ $\left[{ }^{3} \mathrm{H}\right]$ oxotremorine $-\mathrm{M}$, respectively. Data are mean \pm SEM (bars) values. ${ }^{*} 0<0.05$ compared with control values by Wilcoxon's rank-sum test. 


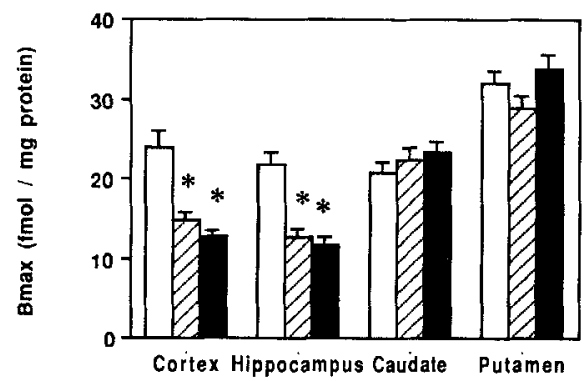

FIG. 3. Specific binding of $(-)-\left[^{3} \mathrm{H}\right]$ nicotine to nicotinic sites in different brain areas from 10 control subjects $(\square)$ and five nondemented (遂) and five demented (0) patients with Parkinson's disease. Saturation analyses were performed in tissue homogenates incubated with $0.5-64 \mathrm{nM}(-)-\left[{ }^{3} \mathrm{H}\right]$ nicotine. Data are mean \pm SEM (bars) values. " $p<0.05$ compared with control values by Wilcoxon's rank-sum test.

son's disease (Perry et al., 1985). Even parkinsonian subjects without cognitive impairment showed markedly decreased cortical ChAT activity in this and previous studies (Ruberg et al., 1982; Dubois et al., 1983) and neuronal loss in the substantia innominata $(\mathrm{Na}-$ kano and Hirano, 1984), indicating the beginning of degeneration in the innominatocortical cholinergic system. A subthreshold dose of scopolamine does not induce a deterioration in performance of control subjects in a memory test battery but does reduce performance of parkinsonian patients without cognitive impairment (Dubois et al., 1987). These findings suggest that nondemented parkinsonian subjects have an alteration of central cholinergic transmission that is involved in memory-related cognitive function.

ChAT activity in the caudate nucleus and putamen was unchanged in this and previous studies (Ruberg et al., 1982; Sirviö et al., 1989), indicating intact striatal cholinergic innervation. This corresponds with neuropathological findings that the striatum is generally free of lesions in Parkinson's disease (Jellinger, 1987). The striatum is rich in cholinergic structures, and lesions of striatal afferents and efferents fail to induce a major loss of ChAT and acetylcholinesterase, indicating that the majority of ChAT is contained in interneurones (Butcher and Butcher, 1974; McGeer et al., 1971).

\section{Muscarinic receptor binding}

The $B_{\max }$ values for specific $\left[{ }^{3} \mathrm{H}\right] \mathrm{QNB}$ binding in the control subjects are well in accord with those reported by others (Ruberg et al., 1982). Thus, $\left[{ }^{3} \mathrm{H}\right]-$ QNB binding was high in the putamen and caudate nucleus, intermediate in the frontal cortex, and low in the hippocampus. A similar distribution was observed for the $B_{\max }$ values for specific $\left[{ }^{3} \mathrm{H}\right]$ pirenzepine binding. These results agree with the findings of previous studies (Cortés et al., 1986; Quirion et al., 1989).

Increased concentrations of the total number of muscarinic cholinergic receptors in Parkinson's disease have been described in previous reports (Ruberg et al., 1982; Sirviö et al., 1989). However, at least some of the patients examined in these studies had received anticholinergic drugs before death, and the increase in receptor numbers was possibly induced by the medication (Westlind et al., 1981). In the present study the parkinsonian patients had not received anticholinergics. The increase in number of muscarinic receptors and in particular of $M_{1}$ receptors, which are thought to be located mainly postsynaptically (Mash et al., 1985), may therefore reflect denervation supersensitivity due to reduced presynaptic cholinergic activity. Altered cholinergic transmission may not, in its early stages, be entirely expressed functionally, because increased concentrations of postsynaptic muscarinic receptors can compensate for the cholinergic deficit and maintain normal cognitive function.

In the cortex the concentration of putative $\mathrm{M}_{2}$ muscarinic receptors identified by specific $\left[{ }^{3} \mathrm{H}\right]$ oxotremorine- $\mathrm{M}$ binding is markedly decreased. A similar reduction of $\left[{ }^{3} \mathrm{H}\right]$ oxotremorine-M binding has been shown in Alzheimer's disease (Mash et al., 1985), and these results appear to support the hypothesis that $\mathbf{M}_{2}$ receptors are located on presynaptic cholinergic nerve terminals and are partly lost due to degeneration of the ascending innominatocortical pathway. This view is supported by the observation that cortical $\left[{ }^{3} \mathrm{H}\right]-$ oxotremorine-M binding is decreased to the same degree as ChAT activity following bilateral nucleus basalis lesions in the rat $(\mathrm{K}$. W. Lange, unpublished data).

The increase in the number of $M_{1}$ receptors and the reduction in number of $\mathrm{M}_{2}$ receptors in the cortex in Parkinson's disease have pharmacological implications. As the cholinergic nerve terminals seem to degenerate in patients with Parkinson's disease, a possible replacement therapy of the cholinergic deficit has to concentrate on postsynaptic $\mathbf{M}_{1}$ receptors. It appears therefore to be necessary to avoid $M_{1}$ antagonists, which are commonly used to treat the motor disorders of parkinsonian patients. Cholinergic replacement as a treatment of the cognitive dysfunction in Parkinson's disease should be beneficial because most of the cortical target cells seem to be intact. There is, however, a risk of aggravating the motor symptoms by cholinergic agonists (Duvoisin, 1967).

The result of unchanged $\left[{ }^{3} \mathrm{H}\right] \mathrm{QNB}$ binding in the caudate nucleus confirms the findings of other studies (Reisine et al., 1977; Ruberg et al., 1982; Sirviö et al., 1989). A decrease in number of muscarinic $M_{1}$ receptors measured by specific $\left[{ }^{3} \mathrm{H}\right]$ pirenzepine binding was previously shown in another study (Sirviö et al., 1989). The connections between cholinergic interneurones and pathways to and from the striatum are not well understood. Animal studies suggest that the nigrostriatal dopaminergic neurones have synaptic contact with ChAT-containing dendritic processes (Hattori et al., 1976) and inhibit the activity of the cholinergic neurones (Connor, 1970). Some muscarinic receptors may be located on dopaminergic nerve terminals in the caudate nucleus (Fibiger, 1982; Gray- 
biel et al., 1986). As dopaminergic neurones projecting from the substantia nigra to the striatum degenerate in Parkinson's disease (Jellinger, 1987), the decrease in the number of $\left[{ }^{3} \mathrm{H}\right]$ pirenzepine binding sites in the striatum could be explained by a possible location of $M_{1}$ receptors on nigrostriatal dopaminergic axon terminals. This view is underlined by the finding that after hemitransection of the nigrostriatal pathway in the rat, a substantial reduction of $\left[{ }^{3} \mathrm{H}\right]-$ pirenzepine receptors is observed in the striatum ipsilateral to the lesion (Pittaluga et al., 1987).

It is interesting to note that the concentrations of $\mathrm{M}_{2}$ binding sites in the cortex, hippocampus, and caudate nucleus of control and parkinsonian subjects are similar when determined by specific $\left[{ }^{3} \mathrm{H}\right]$ oxotremorine- $\mathrm{M}$ binding or by the subtractive method using the difference between $\left[{ }^{3} \mathrm{H}\right] \mathrm{QNB}$ binding and $\left[{ }^{3} \mathrm{H}\right]-$ pirenzepine binding as an estimate for $\mathrm{M}_{2}$ site density (Fig. 2). These values are, however, quite different in the putamen. There was no alteration in the concentration of $\mathrm{M}_{2}$ sites when determined by $\left[{ }^{3} \mathrm{H}\right]$ oxotremorine- $\mathrm{M}$ binding, but there appears to be an increase when determined by the subtractive method (Fig. 2).

\section{Nicotinic receptor binding}

In control subjects the putamen showed the highest level of specific $(-)-\left[{ }^{3} \mathrm{H}\right]$ nicotine binding, with lower binding being seen in the frontal cortex, hippocampus, and caudate nucleus. This distribution was in good agreement with data reported previously (Shimohama et al., 1986).

As the subjects examined had not been smokers in the 2 years before death, an increase in the density of $(-)-\left[{ }^{3} \mathrm{H}\right]$ nicotine binding sites as a result of tobacco smoking can probably be excluded (Benwell et al., 1988). The present results suggest that the concentrations of cortical and hippocampal nicotinic receptors are reduced in Parkinson's disease. Reduced nicotinic receptor binding was previously reported in the hippocampus (Perry et al., 1987) and cortex (Whitehouse et al., 1988a,b). The exact cellular location of nicotinic receptors in the cortex and hippocampus is not known. The parallel changes in these receptors and ChAT activity suggest that the receptor is at least partly associated with cholinergic innervation and presumably located presynaptically on degenerating cholinergic axons. The nucleus basalis of Meynert, which is the principal nucleus of the basal forebrain cholinergic system and innervates the cortex, has the highest concentrations of nicotinic receptors in the human brain (Shimohama et al., 1986). The degeneration of nucleus basalis neurones in Parkinson's disease may result in reductions in content of cortical presynaptic markers, including nicotinic receptors. Consistent with the idea of presynaptic location of nicotinic binding sites is the finding that nicotine stimulates the release of acetylcholine from cholinergic terminals in the cortex (Balfour, 1982; Rowell and Winkler, 1984).

Nicotine affects performance in various attentional tasks, including those requiring vigilance and divided attention (Wesnes and Warburton, 1983). In animals and humans nicotinic agonists have been shown to improve performance on learning tasks (Flood et al., 1981; Wesnes and Warburton, 1984). The present findings of reduced numbers of cortical nicotinic receptors point to the potential for stimulation of the remaining nicotinic receptors with nicotinic agonists as a treatment of the cholinergic deficit associated with cognitive impairment in Parkinson's disease.

Acknowledgment: Brain tissue specimens were obtained from the Parkinson's Disease Society Brain Bank at the Institute of Neurology in London. This study was supported by the Deutsche Forschungsgemeinschaft (grant La 580/1-11), the Medical Research Council, and the Parkinson's Disease Society.

\section{REFERENCES}

American Psychiatric Association (1980) Diagnostic and Statistical Manual of Mental Disorders, 3rd ed. American Psychiatric Association, Washington, D.C.

Balfour D. J. K. (1982) The effects of nicotine on brain neurotransmitter systems. Pharmacol. Ther, 16, 269-282.

Bartus R. T., Dean R. L. III, Beer B., and Lippa A. S. (1982) The cholinergic hypothesis of geriatric memory dysfunction. Science 217, 408-417.

Benwell M. E. M., Balfour D. J. K., and Anderson J. M. (1988) Evidence that tobacco smoking increases the density of $(-)$ $\left[{ }^{3} \mathrm{H}\right]$ nicotine binding sites in human brain. J. Neurochem. 50, 1243-1247.

Bevan P. (1984) $\left[{ }^{3} \mathrm{H}\right]$ Oxotremorine-M binding to membranes prepared from rat brain and heart: evidence for subtypes of muscarinic receptors. Eur. J. Pharmacol. 101, 101-110.

Bradford M. M. (1976) A rapid and sensitive method for the quantification of microgram quantities of protein utilizing the principle of protein-dye binding. Anal. Biochem. 72, 248-254.

Butcher S. H. and Butcher L. L. (1974) Origin and modulation of acetylcholine activity in the neostriatum. Brain Res. 71, 167171.

Candy J. M., Perry R. H., Perry E. K., Irving D., Blessed G., Fairbairn A. F., and Tomlinson B. E. (1983) Pathological changes in the nucleus of Meynert in Alzheimer's and Parkinson's diseases. J. Neurol. Sci. 54, 277-289.

Connor J. D. (1970) Caudate nucleus neurons: correlation of the effects of substantia nigra stimulation with iontophoretic dopamine. J. Physiol. (Lond.) 208, 691-703.

Cortés R., Probst A., Tobler H.-J., and Palacios J. M. (1986) Muscarinic cholinergic receptor subtypes in the human brain. II. Quantitative autoradiographic studies. Brain Res. 362, 239253.

Dubois B., Ruberg M., Javoy-Agid F., Ploska A., and Agid Y. (1983) A subcortico-cortical cholinergic system is affected in Parkinson's disease. Brain Res. 288, 213-218.

Dubois B., Danzé F., Pillon B., Cusimano G., Lhermitte F., and Agid Y. (1987) Cholinergic-dependent cognitive deficits in Parkinson's disease. Ann. Neurol. 22, 26-30.

Duvoisin R. C. (1967) Cholinergic-anticholinergic antagonism in parkinsonism. Arch. Neurol. 17, 124-136.

Everitt B. J., Robbins T. W., Evenden J. L., Marston H, M., Jones G. H., and Sirkiä T. E. (1987) The effects of excitotoxic lesions of the substantia innominata, ventral and dorsal globus pallidus on the acquisition and retention of a conditional visual discrimination: implications for cholinergic hypotheses of learning and memory. Neuroscience 22, 441-469.

Fibiger H. C. (1982) The organization and some projections of cho- 
linergic neurons of the mammalian forebrain. Brain Res. Rev. 4, 327-388.

Flood J. F., Landry D. W., and Jarvik M. E. (1981) Cholinergic receptor interactions and their effects on long-term memory processing. Brain Res. 215, 177-185.

Fonnum F. (1975) A rapid radiochemical method for the determination of choline acetyltransferase. $J$. Neurochem. 24, 407409.

Graybiel A. M., Baugham R. W., and Eckenstein F. (1986) Cholinergic neuropil of the striatum observes striosomal boundaries. Nature 323, 625-627.

Hammer R., Berrie C. P., Birdsall N. J. M., Burgen A. S. V., and Hulme E. C. (1980) Pirenzepine distinguishes between different subclasses of muscarinic receptors. Nature 283, 90-92.

Hattori T., Singh V. K., McGeer E. G., and McGeer P. L. (1976) Immunohistochemical localization of choline acetyltransferase containing neostriatal neurons and their relationship with dopaminergic synapses. Brain Res. 102, 164-173.

Jellinger K. (1987) The pathology of parkinsonism, in Movement Disorders 2 (Marsden C. D. and Fahn S., eds), pp. 124-165. Butterworths, London.

Mash D. C., Flynn D. D., and Potter L. T. (1985) Loss of M2 muscarine receptors in the cerebral cortex in Alzheimer's disease and experimental cholinergic denervation. Science 228, $1115-1117$.

McGeer P. L., McGeer E. G., Fibiger H. C., and Wickson V. (1971) Neostriatal choline acetylase and cholinesterase following selective brain lesions. Brain Res. 35, 308-314.

Nakano I. and Hirano A. (1984) Parkinson's disease: neuron loss in the nucleus basalis without concomitant Alzheimer's disease. Ann. Neurol. 15, 415-418.

Perry E. K., Tomlinson B. E., Blessed G., Bergmann K., Gibson P. H., and Perry R. H. (1978) Correlation of cholinergic abnormalities with senile plaques and mental test scores in senile dementia. Br. Med. J. 2, 1457-1459.

Perry E. K., Curtis M., Dick D. J., Candy J. M., Atack J. R., Bloxham C. A., Blessed G., Fairbairn A., Tomlinson B. E., and Perry R. H. (1985) Cholinergic correlates of cognitive impairment in Parkinson's disease: comparisons with Alzheimer's disease. J. Neurol. Neurosurg. Psychiatry 48, 413-421.

Perry E. K., Perry R. H., Smith C. J., Dick D. J., Candy J. M., Edwardson J. A., Fairbairn A., and Blessed G. (1987) Nicotinic receptor abnormalities in Alzheimer's and Parkinson's diseases. J. Neurol. Neurosurg. Psychiatry 50, 806-809.

Pittaluga A., Versace P., Marchi M., and Raiteri M. (1987) [ $\left.{ }^{3} \mathrm{H}\right]-$ Pirenzepine binding in rat corpus striatum decreases after hemitransection of the nigro-striatal pathway. Fundam. Clin. Pharmacol. 1, 317-325.

Quirion R., Aubert I., Lapchak P. A., Schaum P. A., Teolis S., Gauthier S., and Araujo D. M. (1989) Muscarinic receptor subtypes in human neurodegenerative disorders: focus on Alzheimer's disease. Trends Pharmacol. Sci. 10 (Suppl), 80-84.

Reisine T. D., Fields J. Z., Yamamura H. I., Bird E., Spokes E., Schreiner P., and Enna S. J. (1977) Neurotransmitter receptor alterations in Parkinson's disease. Life Sci. 21, 335-344.

Ridley R. M., Baker H. F., Drewett B. S., and Johnson J. A. (1985) Effects of ibotenic acid lesions of the basal forebrain on serial reversal learning in the marmoset. Psychopharmacology (Berlin) $86,438-449$.
Romano C. and Goldstein A. (1980) Stereospecific nicotine receptors in rat brain membranes. Science 210, 647-650.

Rowell P. P. and Winkler D. L. (1984) Nicotinic stimulation of $\left[{ }^{3} \mathrm{H}\right]$ acetylcholine release from mouse cerebral cortical synaptosomes. J. Neurochem. 43, 1593-1598.

Ruberg M., Ploska A., Javoy-Agid F., and Agid Y. (1982) Muscarinic binding and choline acetyltransferase activity in parkinsonian subjects with reference to dementia. Brain Res. 232, 129-139.

Shimohama S., Taniguchi T., Fujiwara M., and Kameyama M. (1985) Biochemical characterization of the nicotinic cholinergic receptors in human brain: binding of $(-)-\left[{ }^{3} \mathrm{H}\right]$ nicotine. $J$. Neurochem. 45, 604-610.

Shimohama S., Taniguchi T., Fujiwara M., and Kameyama M. (1986) Changes in nicotinic and muscarinic cholinergic receptors in Alzheimer-type dementia. J. Neurochem. 46, 288-293.

Sirviö J., Rinne J. O., Valjakka A., Rinne U. K., Riekkinen P. J., and Paljärvi L. (1989) Different forms of brain acetylcholinesterase and muscarinic binding in Parkinson's disease. $J$. Neurol. Sci. 90, 23-32.

Smith C. J., Perry E. K., Perry R. H., Candy J. M., Johnson M., Bonham J. R., Dick D. J., Fairbairn A., Blessed G, and Birdsall N. J. M. (1988) Muscarinic cholinergic receptor subtypes in hippocampus in human cognitive disorders. $J$. Neurochem. $\mathbf{5 0 ,} 847-856$.

Spencer D. G. Jr., Horváth E., and Traber J. (1986) Direct autoradiographic determination of M1 and M2 muscarinic acetylcholine receptor distribution in the rat brain: relation to cholinergic nuclei and projections. Brain Res. 380, 59-68.

Watson M., Yamamura H. I., and Roeske W. R. (1983) A unique regulatory profile and regional distribution of $\left[{ }^{3} \mathrm{H}\right]$ pirenzepine in the rat provide evidence for distinct $\mathrm{M} 1$ and $\mathrm{M} 2$ muscarinic receptor subtypes. Life Sci. 32, 3001-3011.

Weller M. E., Rose S., Jenner P., and Marsden C. D. (1987) In vitro characterisation of dopamine receptors in the superior colliculus of the rat. Neuropharmacology 26, 347-354.

Wesnes K. and Warburton D. M. (1983) Smoking, nicotine, and human performance. Pharmacol. Ther. 21, 189-208.

Wesnes K. and Warburton D. M. (1984) Effects of scopolamine and nicotine in human rapid information processing performance. Psychopharmacology (Berlin) 82, 147-150.

Westlind A., Grynfarb M., Hedlund B., Bartfai T., and Fuxe K. (1981) Muscarinic supersensitivity induced by septal lesion or chronic atropine treatment. Brain Res. 225, 131-141.

Whitehouse P. J., Hedreen J. C., White C. L. III, and Price D. L. (1983) Basal forebrain neurons in the dementia of Parkinson's disease. Ann. Neurol. 13, 243-248.

Whitehouse P. J., Martino A. M., Marcus K. A., Zweig R. M., Singer H. S., Price D. L., and Kellar K. J. (1988a) Reductions in acetylcholine and nicotine binding in several degenerative diseases. Arch. Neurol. 45, 722-724.

Whitehouse P. J., Martino A. M., Wagster M. V., Price D. L., Mayeux R., Atack J. R., and Kellar K. J. (1988b) Reductions in $\left[{ }^{3} \mathrm{H}\right]$ nicotinic acetylcholine binding in Alzheimer's disease and Parkinson's disease: an autoradiographic study. Neurology 38, 720-723.

Wilcoxon F. (1945) Individual comparisons by ranking methods. Biometrics 1, 80-83. 